Acta Crystallographica Section A

Foundations of Crystallography

ISSN 0108-7673

\section{International Union of Crystallography Twentieth General Assembly and International Congress of Crystallography Florence, Italy, 23-31 August 2005}

\section{Introduction and Opening Ceremony}

By invitation of the National Research Council and the Italian National Committee for Crystallography, the Twentieth General Assembly and International Congress of Crystallography were held at the Fortezza da Basso Conference Centre, Florence, Italy, 23-31 August 2005.

The meetings were attended by about 2,800 participants and 200 accompanying persons from 62 countries.

The General Assembly and Congress were opened on the evening of 23 August at the Congress Centre. Welcoming Addresses were made by Dr J. MAKHUBALO (Director, International Cooperation and Assistance Division of the Organization for the Prohibition of Chemical Weapons), Professor I. BERTINI (University of Florence), Professor P. PAOLI (Chair of Local Organizing Committee), Mr S. SILIONI (City of Florence Council), Mr G. BINGEN (European Commission), Professor C. MEALLI (Chair of Programme Committee), Professor P. SPADON (President of the Italian Crystallographic Association) and Professor W. L. DUAX (President of the IUCr). There followed a musical interlude. The Ewald Prize was then accepted by Professor P. COPPENS, who presented the Ewald Address. The first IUCr Award for Exceptional Service to Crystallography to Professor L. RIVA DI SANSEVERINO was announced. There was then a colourful parade of historical characters from the Republic of Firenze. The evening ended with a Welcoming Cocktail Party.

\section{Twentieth International Congress}

\subsection{Scientific programme}

36 Keynote Lectures, 98 Microsymposia and 8 Open Commission Meetings were held during morning and late afternoon sessions. The early afternoon sessions were reserved for poster sessions. The abstracts in the published book of Collected Abstracts were prepared from electronic submissions and were also provided on a CD-ROM.

\subsection{Exhibitions}

A commercial exhibition comprising 52 companies and booksellers was organized. Computer terminals and a designated area with a wireless hotpoint were provided to enable e-mail access for all attendees.

\subsection{Social events}

In addition to the Welcoming Cocktail Party there was an Exhibition on Art and Crystallography. Evening entertainments included a concert, a banquet (at which the IUCr Award for Exceptional
Service to Crystallography was presented to L. RIVA DI SANSEVERINO), a dinner for General Assembly delegates and Keynote Lecturers, and a Closing Ceremony. Various excursions were also arranged.

\section{Minutes of the Twentieth General Assembly}

These Minutes have been prepared by M. H. Dacombe, Executive Secretary, under the authority of S. Larsen, General Secretary and Treasurer of the IUCr and Secretary of the General Assembly.

\subsection{Introduction and list of delegates}

Sessions of the General Assembly were held on the evenings of Wednesday 24 August, Thursday 25 August and Sunday 28 August. It was not found necessary to meet on Monday 29 August, as originally planned. The following attendance list gives the names of official delegates appointed by the Adhering Bodies and the alternates who substituted at one or more sessions. Dates of attendance are given in parentheses for those who were not present at every session. The names are listed by the countries to which the respective Adhering Bodies belong, and the number of votes of the Adhering Body is given in parentheses after the name of the country. The names of the Chairs of the delegations are given in bold where they are known; those of alternates are marked by an asterisk. The Category of Adherence for Brazil was reduced to 1 at the first session, that for Russia was increased to 5. There was no delegate from Bulgaria.

Argentina (1): R. Baggio

Australia (3): P. Colman, J. M. Guss, J. Martin

Austria (1): H. S. Effenberger* (24 August), E. Tillmanns (25 and 28 August)

Belgium (2): K. Michel, B. Tinant (25 August)

Brazil (1): G. Oliva (24 and 28 August), Y. Mascarenhas* (25 August)

Canada (3): T. S. Cameron, L. T. J. Delbaere, S. Fortier

Chile (1): M. T. Garland

China, People's Republic (4): Z. Rao (24 August), X.-D. Su, D. Yao* (25 and 28 August), B. Zhang (25 August)

China, The Academy of Sciences Located in Taipei (2): S. L. Chung, C. D. Shiaw

Croatia (1): S. Popović

Czech/Slovak Republics (2): R. Kuzel, Z. Šourek

Denmark (1): F. K. Larsen (28 August), E. Mackovicky* (25 August)

Egypt (1): Y. Abbas (non-voting)

Finland (1): K. Hämäläinen

France (4): P. Damas (24 and 25 August), J.-C. Daran, J.-L. Hodeau, C. Lecomte, A. Podjarny* (28 August) 
Germany (4): W. Depmeier, P. Luger (24 and 25 August), W. Neumann, U. Pietsch* (28 August), E. Weckert

Greece (1): I. Mavridis

Hungary (1): P. Bombicz* (25 August), A. Kálmán (24 and 28 August)

India (2): D. Pandey, M. Vijayan

Israel (1): N. Adir

Italy (3): G. Filippini, R. Oberti, P. Spadon

Japan (4): T. Kamiyama, K. Ohsumi (24 and 28 August), Y. Kai*, S.

Sasaki, M. Takata* (25 August)

Korea (1): H. M. Park*

Mexico (1): L. Bucio Galindo

The Netherlands (2): S. Harkema, E. Vlieg (25 and 28 August)

New Zealand (1): G. J. Gainsford

Norway (1): C. H. Görbitz

Poland (1): A. Pietraszko

Portugal (1): M. M. R. R. da Costa (28 August)

Russia (5): M. Yu. Antipin, A. S. Avilov, M. V. Kovalchuk, I. P.

Makarova, D. Yu. Pushcharovsky

Serbia (1): G. A. Bogdanovic

Slovenia (1): I. Leban (24 and 25 August)

South Africa (2): J. C. A. Boeyens* (28 August), S. A. Bourne, D. C.

Levendis (24 and 25 August)

Spain (3): S. García-Granda, C. Miravitlles, E. Gutiérrez-Puebla

Sweden (2): S. Lidin, A. Liljas (24 and 28 August)

Switzerland (2): R. Cerny (25 and 28 August), H. Grimmer, W.

Steurer* (24 August)

Ukraine (1): R. Gladyshevskii (24 August; non-voting)

UK (5): J. S. O. Evans, E. Garman, R. O. Gould, S. B. Gould, C. C. Wilson

USA (5): J. Clardy, J. L. Flippen-Anderson, J. A. Kaduk, K. Kantardjieff, B. Toby

Venezuela (1): G. Diaz de Delgado

Present as members of the Executive Committee: W. L. Duax (President), L. A. Aslanov (Vice-President), S. Larsen (General Secretary and Treasurer), H. Schenk (Immediate Past President), M. A. Carrondo, G. Heger, Y. Ohashi, I. Torriani, D. Viterbo, Z. Zhang (24 August) (Ordinary Members). M. H. Dacombe was in attendance as Executive Secretary.

\subsection{First Session, Wednesday 24 August 2005, 7:15 p.m.}

(1) Introductory remarks by the President

Professor DUAX welcomed the delegates and observers.

(2) Procedural matters

In order to verify the list of voting delegates, the President requested the General Secretary to read this list, and asked delegates to indicate their presence when their names were called. (This procedure was repeated at the beginning of each session of the General Assembly.)

Two delegates, one from Croatia and one from Venezuela, were appointed to act as tellers when votes had to be counted during the Assembly.

(3) Approval of Agenda

The Agenda and Appendices to the Agenda had been distributed to Secretaries of National Committees in May 2005. The Agenda were approved.

(4) Amendments to Statutes and By-Laws affecting adherence to the Union

The President reported that there were no proposals.

(5) Applications for membership of the Union

An application for membership of the IUCr had been received from the Hellenic Crystallographic Association (Category I) and the
Executive Committee recommended to the General Assembly that this be accepted. The application was accepted by the General Assembly with applause and the delegate from Greece took her seat.

(6) Withdrawal of Adhering Bodies

The President reported that since the Geneva Congress the arrears in subscriptions for Argentina had been paid by the USA National Committee for Crystallography, the American Crystallographic Association and the Spanish Adhering Body. The Adhering Body for Argentina had confirmed that it was in a position to pay future dues and the Executive Committee had accordingly reinstated its membership. The reinstatement of the Adhering Body for Argentina was confirmed by the General Assembly.

The President reported that the Adhering Bodies for Ukraine and Bulgaria were both more than four years in arrears and their membership had been suspended automatically in accordance with Statute 9.6. He confirmed that if their memberships were withdrawn their arrears of dues would not be taken into account should they reapply for membership at a future General Assembly. The General Assembly confirmed the withdrawal of the Adhering Bodies for Ukraine and Bulgaria.

(7) Changes in names of Adhering Bodies

The changes in names of the Adhering Bodies of Brazil (to the Brazilian Crystallographic Association) and Spain (to the Subdirección General de Organismos y Programas Internacionales, Ministerio de Ciencia y Tecnologia) were accepted by the General Assembly.

(8) Changes in Category of Adherence of Adhering Bodies

The change in Category of Adherence of the Adhering Body for Brazil (the Brazilian Crystallographic Association) from Category III to Category I was approved by the General Assembly. The change in Category of Adherence of the Adhering Body for Russia (the Russian Academy of Sciences) from Category IV to Category V was approved by the General Assembly.

(9) Approval of Minutes of Nineteenth General Assembly

The Minutes, which were contained in the published Report of the Nineteenth General Assembly and International Congress of Crystallography [Acta Cryst. (2003), A59, 374-433], were approved and two copies were signed by the President and the General Secretary, in accordance with By-Law 1.13. There were no matters arising from the Minutes.

(10) Amendments to Statutes and By-Laws not affecting adherence to the Union

The President reported that there were no proposals.

(11) Report of Executive Committee

The Report of the Executive Committee on the activities of the IUCr since the Nineteenth General Assembly had been submitted to the National Committees and the Commissions in May 2005, in accordance with Statute 6.8, and follows these Minutes as Annex I, Appendix A. The President reported that the Executive Committee appreciated the hard work of the Commissions, staff and delegates. He thanked the General Assembly for entrusting him with the Presidency. The Report was accepted without discussion.

(12) Financial Report

A Financial Report, covering the calendar years 2002, 2003 and 2004, had been prepared by the Treasurer and had been submitted to the National Committees and the Commissions in May 2005. The Report follows these Minutes as Annex I, Appendix B.

The Treasurer noted that this was the fourth report to the General Assembly that she had presented (she had initially been appointed prior to the Seattle General Assembly in 1996). She commented that among the Scientific Unions the IUCr was unusual in having its own publishing programme and she had much enjoyed following the many developments since 1996. She emphasized the importance of the 
Finance Committee and of its having two UK members. The Union operated in three currencies: member subscriptions were largely paid in $\mathrm{CHF}$, two-thirds of the investments, income and most expenses were in GBP, and one-third of the investments and some expenses were in USD. The Treasurer highlighted the weakening of the USD and (less so) the GBP against the CHF over recent years. The Union had been operating at a loss during the first two years of the triennium whilst significant investment in Crystallography Journals Online and International Tables was being made. The bulk of this work had now been completed and the Union had returned to making a small overall profit in 2004. A profit would have been made in 2003 but one of the main subscription agents had become bankrupt and the dollar prices had been adjusted to come into line with Blackwell's exchange rates.

The main income generators were member subscriptions, investments, International Tables and journals. The Union was able to maintain membership subscriptions at a low level (these accounted for about $3 \%$ of total income) because of income from publications. Regular contact was maintained between members of the Finance Committee and the Fund managers handling the investments. During the triennium the funds handled in Jersey by F\&C had been transferred to Close Finsbury Holdings ( $\mathrm{F} \& \mathrm{C}$ had closed the funds in which the Union's money had been invested). The transfer of about CHF 2.6M had been made free of costs. Since 2002, the performance of the markets had been steadily improving and the Union's investments had followed that trend. The present balance of the assets was $58 \%$ equities and $42 \%$ bonds and cash. The present series of International Tables had been completed with the publication of Volume $\mathrm{G}$ in 2005. An online version was under development and would become available during 2006. The Treasurer reviewed the history of the journals from the first issue of Acta Crystallographica in 1948, the split into Acta A and Acta B and the launch of Journal of Applied Crystallography in 1968, Acta C in 1983, Acta D in 1993, Journal of Synchrotron Radiation in 1994, Acta E in 2001 and Acta F in 2005. In 1991 the Crystallographic Information File (CIF) had been adopted, in 1998 online access had been made available and in 2002 the Union became the first publisher to make all its back issues available online. The total number of journal pages published had increased by about $75 \%$ over the past ten years but the number of printed pages had fallen by about $12 \%$, reflecting the popularity of the online-only journals (Acta E and Acta F). It was the excess of income over expenditure from the journals (amounting to about $15 \%$ each year) that financed the good work of the Union (young scientist support, for example). The trends of falling journal subscriptions (common to all publishers), increase in numbers of submitted papers and increase in numbers of published pages had been countered by inclusion of the Union's journals in Blackwell's Synergy server in 2003, a new more favourable contract with Blackwell Munksgaard, income from consortial sales from 2004 and the introduction of an open access option in 2003. The Treasurer was pleased to report that the Union was continuing the transformation to a modern, leading publishing organization. To support this she cited the award of a grant of GBP 32,500 in each of 2004 and 2005 [subsequently renewed for 2006] from the UK Joint Information Systems Committee to enable the Union's open-access charge to be waived for UK authors in the relevant years. The Union was one of only five recipients of an award.

The Treasurer summarized the past ten years by stating that there was now active promotion through the Promotions Officer, the Union was at the leading edge of publication, the assets were better balanced, there was additional income through consortial sales, a favourable contract had been negotiated with Blackwell Munksgaard, the finances were reasonably healthy and there was a competent and productive staff in Chester. She had found the past ten years challenging and the Executive Committee had worked hard promoting the Union. She thanked the Presidents she had worked with, the members of the Finance Committee and especially its Convener (Professor M. J. Cooper) and investment adviser (Dr S. G. Fleet), the Editor-in-Chief (Professor J. R. Helliwell) and the Chester staff.

The General Assembly thanked the Treasurer for her report with standing applause.

J. A. KADUK asked whether the Union had a pricing model for the online version of International Tables. The Treasurer replied that the exact terms for inclusion of International Tables in SpringerLink were still under negotiation and the pricing model still had to be decided.

The President thanked the Treasurer for her devoted work for the Union and the General Assembly accepted the Financial Report.

(13) Ewald Prize

Details of the Prize, awarded to Professor P. Coppens at the Opening Ceremony, and the citation are given in Annex I, Appendix C.

The Selection Committee was thanked for its work.

(14) Commission on Journals

The Report of the Commission on Journals had been distributed to the National Committees and the Commissions in May 2005 and is reprinted in Annex I, Appendix D.

The Chair (J. R. HELLIWELL) highlighted the fact that publication policies of funding agencies were changing with a trend especially towards making medically oriented papers freely available. On the positive side, the profit margin of the Union's journals was intentionally small and the Union was committed to a fair and transparent pricing structure. The Union was well placed to take advantage of new opportunities. The Chair had enjoyed his term as Editor-in-Chief and thanked the Executive Committee, the Finance Committee, the Chester staff and the Treasurer. The General Assembly accepted the report with applause.

(15) Commission on International Tables

The Report by the Chair of the Commission on International Tables had been distributed to the National Committees and the Commissions in May 2005 and is reprinted in Annex I, Appendix D.

The President noted that Professor H. FUESS had taken over as Chair of the Commission in 2003.

The Chair thanked the previous Chair (Professor Th. Hahn) and all the Editors for a marvellous job. He welcomed any suggestions on how to develop International Tables.

The Report was accepted with applause.

(16) Committee on Electronic Publishing, Dissemination and Storage of Information

The Report of the Chair of the Committee on Electronic Publishing, Dissemination and Storage of Information had been distributed to the National Committees and the Commissions in May 2005 and is reprinted in Annex I, Appendix E.

The Chair (H. D. FLACK) noted that in the coming triennium work would be needed to restyle the Union's web site. The number of entries in the World Directory of Crystallographers should also be increased to make it more useful. He thanked the Executive Committee for continuing support of the Crystallographic neXus project. More educational material should be made available online. He also mentioned the work of the ebank project for institutional archiving of crystal structures, being developed at the University of Southampton, UK.

The President thanked the Chair for his excellent work. 
(17) Committee for the Maintenance of the CIF Standard (COMCIFS)

The Report of the Chair of the Committee for the Maintenance of the CIF Standard (COMCIFS) had been distributed to the National Committees and the Commissions in May 2005 and is reprinted in Annex I, Appendix F.

The Chair (I. D. BROWN) commented that the Union had been well ahead in the information technology field with the development and use of the Crystallographic Information File but that decisions on how best to proceed in the current state of information technology would soon need to be made.

The President thanked the Chair for his work.

(18) Committee on Crystallographic Databases

The Report of the Chair of the Committee on Crystallographic Databases had been distributed to the National Committees and the Commissions in May 2005 and is reprinted in Annex I, Appendix G. (19) IUCr Newsletter

The Report of the Editor of the IUCr Newsletter had been distributed to the National Committees and the Commissions in May 2005 and is reprinted in Annex I, Appendix H.

J. L. FLIPPEN-ANDERSON (the Editor of the Newsletter) particularly thanked Patti Coley for her work on producing the Newsletter. She noted that the special issues highlighting crystallography in different countries had been especially successful.

The President thanked the Editor for her work.

(20) IUCr/Oxford University Press Book Series

The Report of the Chair had been distributed to the National Committees and the Commissions in May 2005 and is reprinted in Annex I, Appendix I.

The Chair (H. SCHENK) noted that 32 books had appeared in the series and that in total more than 25,000 had been sold. He welcomed new suggestions for this successful series.

(21) Non-publishing Commissions

The reports of the Commissions on their activities since the Nineteenth General Assembly had been distributed to the National Committees and the Commissions in May 2005. The reports are reprinted in Annex I, Appendix D.

The President reported that the Executive Committee had had indepth discussions with the Chairs. The importance of regular turnover of membership had been emphasized, with Chairs not normally serving more than one term. The need for gender balance should be considered and good communication via email was important. The Executive Committee would prepare a list of tasks to be assigned to Commission members to increase activity and encourage cooperation between Commissions.

The reports were taken as read, but the Chair of each Commission, or his or her alternate, accepted the invitation of the President to say a few words about future developments and to answer any questions.

The President thanked all the Chairs for their work.

The General Assembly accepted with applause all the reports that had been received on the activities of the non-publishing Commissions.

The President then adjourned the session at 9:05 p.m.

\subsection{Second Session, Thursday 25 August 2005, 7:10 p.m.}

\section{(22) Proposal for new Commissions}

The President reported that a formal proposal had been received to establish a Commission on Mathematical and Theoretical Crystallography. The Executive Committee had considered the terms of

reference and proposed membership and recommended that the Commission should be established.

The General Assembly approved the formation of a Commission on Mathematical and Theoretical Crystallography.

(23) Review of existing Commissions

The President reported that the Executive Committee had considered the work of the Commissions and had no recommendations to modify or discontinue any of the Commissions. He noted that the action taken within the triennium to change the Chairs of two inactive Commissions had proved successful.

(24) Determination of number of elected members of each Commission

In accordance with Statute $5.10(d)$, the Assembly had to determine the number of persons to be elected on the Commissions until the Twenty-First General Assembly; these numbers did not include Chairs, Co-editors or ex officio members. The numbers of elected members approved by the General Assembly (Chairs not included) are set out below:

1. Commission on Journals 0

2. Commission on International Tables

3. Commission on Aperiodic Crystals

4. Commission on Biological Macromolecules

5. Commission on Charge, Spin and Momentum Densities

6. Commission on Crystal Growth and Characterization of Materials

7. Commission on Crystallographic Computing

8. Commission on Crystallographic Nomenclature

9. Commission on Crystallographic Teaching

10. Commission on Electron Diffraction

11. Commission on High Pressure

12. Commission on Inorganic and Mineral Structures

13. Commission on Mathematical and Theoretical

Crystallography

14. Commission on Neutron Scattering

15. Commission on Powder Diffraction

16. Commission on Small-Angle Scattering

17. Commission on Structural Chemistry

18. Commission on Synchrotron Radiation

19. Commission on XAFS

0

8

10

9

8

8

0

9

8

(25) Reports of Representatives on Regional and Scientific Associates

In accordance with Statute 8.5, the reports of the Representatives on Regional and Scientific Associates had been circulated with the Agenda papers in May 2005. These reports are reprinted as Annex I, Appendix K.

The President noted that in the coming triennium the Executive Committee would consider ways to increase involvement of the Regional Associates with the work of the Union.

M. VIJAYAN reported that the next joint meeting of AsCA with a national crystallographic association would be in Japan in 2006 and that AsCA was continuing its outreach programme to countries presently less involved with AsCA.

H. FUESS reported that the ECA was proud that almost all the northern African countries had become members.

J. A. KADUK (Chair of Board of Directors at the ICDD) looked forward to future close cooperation with the Union in areas such as archiving and publication. He thought the Union could play a role in mediating possible conflicts within the inorganic structures community where different databases were competing. 
All the reports were accepted.

(26) Reports of Representatives on bodies not belonging to the Union

In accordance with Statute 8.5, the reports of the Representatives had been circulated with the Agenda papers in May 2005. These reports are reprinted as Annex I, Appendix L.

The President noted that the IUCr Representative (B. MCMAHON) had been active in guiding the policies of CODATA. He had emphasized that good science must rest on good quality data and that this must apply on a global scale as much as on a laboratory scale. He was thanked with applause by the General Assembly.

It was noted that the ICSU Committee on Science and Technology in Developing Countries - Incorporating International Biosciences and Other Scientific Networks (COSTED-IBN) had been dissolved in September 2002 and that the ICSU Programme on Capacity Building in Science (PCBS) had been discontinued at the end of 2003.

The President reported that the IUCr Representative (P. R. STRICKLAND) had been active in ICSTI and had undertaken a study on the long-term availability of digital publications and data in the field of crystallography. He was thanked with applause by the General Assembly.

All the reports were accepted.

(27) Sponsorship of meetings: Sub-committee on the Union Calendar

The Report of the Chair had been distributed to the National Committees and the Commissions in May 2005 and is reprinted in Annex I, Appendix J.

The President noted that this was a very active Committee that did an important job. The Chair (M. A. CARRONDO) thanked the members for their work. She reported that during the triennium the Guidelines had been revised and that applications were considered on a quarterly basis. There was improved consultation with the Commissions and special attention was paid to supporting meetings in developing countries.

(28) Confirmation of date and place of Twenty-First General Assembly

The invitation from the Science Council of Japan and the Japanese National Committee for Crystallography to hold the Congress and General Assembly in Osaka, Japan, 23-30 August 2008, which had been preliminarily accepted in 2002, was formally accepted.

(29) Preliminary consideration of date and place of Twenty-Second General Assembly

In accordance with By-Law 1.3, the General Assembly could give preliminary consideration to the place of the next but one General Assembly, namely the Twenty-Second General Assembly to be held in 2011. The President announced that invitations had been received from the Regional Committee of the Czech and Slovak Crystallographic Association to hold the Congress in Prague, Czech Republic, and from the Spanish Committee for Crystallography on behalf of the Subdirección General de Programas y Organismos Internacionales, Ministerio Educacíon y Ciencia to hold the Congress in Madrid, Spain. He reported that the Executive Committee had considered both applications and found them to be in order. R. KUZEL presented the formal invitation for the Czech and Slovak Republics and E. GUTIERREZ-PUEBLA presented the formal invitation for Spain. A decision on which invitation to accept was delayed until the next session to give the delegates time to consider the choice [see Minute (34)].

(30) Determination of general policy and timetable for period to Twenty-First General Assembly

There were no comments on this item.
(31) Preliminary consideration of activities for period 2008-2011. There were no comments on this item.

(32) Budget estimates for period to Twenty-First General Assembly: determination of unit contribution

These budget estimates had been distributed with the Agenda papers and are printed as Annex I, Appendix M to these Minutes.

The General Assembly accepted the budget estimates and approved with applause the recommendation of the Executive Committee to continue the unit contribution unchanged, at $\mathrm{CHF}$ 1,000, for the years 2006, 2007 and 2008.

(33) Confirmation of appointments of Editors of publications of the Union

In accordance with Statute 7.1, the initial appointments and the reappointments of the Editors of the publications of the IUCr were made by the Executive Committee and were subject to confirmation by the General Assembly.

The Assembly unanimously confirmed the following appointments and reappointments for the period of three years:

Editor-in-Chief of IUCr journals: G. Kostorz (Switzerland)

Editor of Section A of Acta Crystallographica: D. Schwarzenbach (Switzerland)

Editor of Section B of Acta Crystallographica: C. P. Brock (USA) Editor of Section $C$ of Acta Crystallographica: G. Ferguson (Canada)

Editors of Section D of Acta Crystallographica: E. N. Baker (New Zealand) and Z. Dauter (USA)

Editors of Section E of Acta Crystallographica: W. Clegg (UK) and D. G. Watson (UK)

Editors of Section F of Acta Crystallographica: H. M. Einspahr (USA) and J. M. Guss (Australia)

Editor of Journal of Applied Crystallography: G. Kostorz (Switzerland)

Editors of Journal of Synchrotron Radiation: Å. Kvick (France), D. M. Mills (USA) and T. Ohta (Japan)

General Editor of International Tables and Editor of Volume C: H.

Fuess (Germany)

Editor of Volume A: Th. Hahn (Germany)

Editor of Volume B: U. Shmueli (Israel)

Editor of Volume D: A. Authier (France)

Editors of Volume E: V. Kopsky (Czech Republic) and D. B. Litvin (USA)

Editors of Volume F: M. G. Rossmann (USA) and E. Arnold (USA)

Editors of Volume G: S. R. Hall (Australia) and B. McMahon (UK)

Editors of Volume A1: H. Wondratschek (Germany) and U. Müller (Germany)

Editor of Volume F1: E. Arnold (USA)

The President adjourned the session at 9:15 p.m.

\subsection{Third Session, Sunday 28 August 2005, 7:00 p.m.}

(34) Preliminary consideration of date and place of Twenty-Second General Assembly (continued)

The General Assembly gave preliminary acceptance to the invitation to hold the Twenty-Second General Assembly in 2011 in Spain. (35) Election of Chairs and members of Commissions

The nominations made by the Executive Committee for the Chairs and members of Commissions, after consultation with the Commissions through their Chairs, had been notified to delegates. 
Since no other nominations had been made by the delegates, the persons recommended by the Executive Committee were considered elected.

The current full memberships of all the Commissions, including the ex officio members, together with the addresses of the Chairs, are given as Annex III.

(36) Election of Representatives on bodies not belonging to the Union and on Regional and Scientific Associates

The nominations made by the Executive Committee for those Representatives to be elected by the General Assembly had been notified to delegates. As no other nominations were made, these persons were considered elected.

The names and addresses of the Representatives of the Union, including those appointed ex officio, are given in Annex III.

(37) Election of Officers of the Union

The President commented that the high number of excellent nominations received for ordinary members of the Executive Committee had been much appreciated by the Executive Committee. The Executive Committee was in favour of presenting only one candidate for each office of President, Vice-President and General Secretary and Treasurer but in favour of presenting a choice for the vacancies for ordinary members. The two nominees for President (Y. Ohashi nominated by the Executive Committee and M. A. Carrondo nominated by delegates) then addressed the General Assembly. The President invited comments on the nominations. L. A. ASLANOV (the retiring Vice-President) spoke in support of the nomination made by the Executive Committee and reviewed the procedure that had led to the nomination; he emphasized that it was the role of the Executive Committee to work as a body to come to an agreed recommendation and accept collective responsibility. G. DELGADO spoke in support of the nomination made by the delegates; she was in favour of electing people who would encourage participation of young people from developing countries with particular regard to good geographic, scientific and gender balance. J. L. FLIPPENANDERSON considered that the General Assembly should have a choice of candidates for President and not rely solely on the recommendation of the Executive Committee. J. C. A. BOEYENS considered the position of President to be sufficiently important that the General Assembly should have the opportunity to make a choice. He would like the Executive Committee to consider seriously the possibility of always nominating at least two people for President. J. L. HODEAU was surprised that a nomination for President had been made by delegates. As a truly international organization it was important that the Executive Committee worked smoothly and efficiently by consensus. He considered that the nomination for President should be the responsibility of the Executive Committee. The President thanked the delegates for their comments.

The nominations made by the Executive Committee for Officers of the Union had been included in the Agenda papers distributed in May 2005. Y. Ohashi (Japan) was nominated for President, I. Torriani (Brazil) for Vice-President and S. Lidin (Sweden) for General Secretary and Treasurer. Six nominations were made for the three six-year vacancies for Ordinary Members: P. Colman (Australia), G. R. Desiraju (India), C. Gilmore (UK), M. Kovalchuk (Russia), C. Lecomte (France) and M. Perez-Mato (Spain). The same six nomi- nations were made for the possible three-year vacancy for an Ordinary Member. M. A. Carrondo (Portugal) was nominated by delegates for the vacancy of President. As there was only one candidate for Vice-President and one candidate for General Secretary and Treasurer these candidates were considered elected. Elections for the President, three Ordinary Members for the normal sixyear term and one vacancy for a three-year term (to complete the term of Y. Ohashi following his election as President) were held by secret ballot. The following nominees were elected:

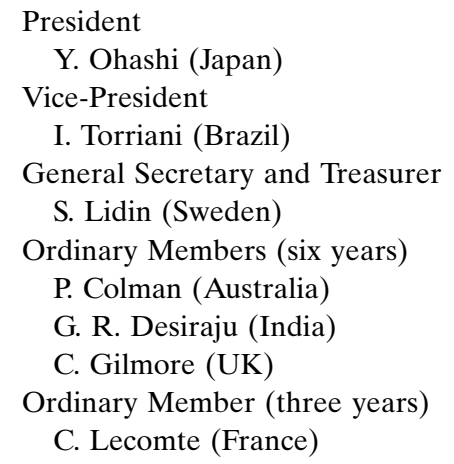

The President congratulated the new members of the Executive Committee and individually thanked those who would be retiring. He particularly thanked S. LARSEN who had served as General Secretary and Treasurer since 1996 and M. A. CARRONDO who had served as Chair of the Sub-committee on the Union Calendar in the past triennium.

At the urging of C. C. WILSON, the General Assembly thanked the President with standing applause for his work during the triennium.

(38) Any other business

As there was no other business and therefore no need for the final session of the General Assembly that had been scheduled for Monday 29 August, the President declared the Twentieth General Assembly closed.

\section{Closing Ceremony, Tuesday 30 August 2005}

C. MEALLI (Chair of the Programme Committee) thanked all involved with making the Congress a success. Three IUCr Poster Prizes in Chemical Crystallography for Younger Scientists sponsored by the Cambridge Crystallographic Data Centre, the Oxford Cryosystems Poster Prize, the Molecular Dimensions Poster Prize and the RCSB PDB Poster prize were awarded. The President then announced and awarded IUCr Prizes for each area covered by the Regional Associates.

Y. OHASHI, the new President, congratulated the organizers for making the Congress such a success. He thanked the retiring President (W. L. DUAX) whose work as President had been highly appreciated. He thanked the retiring members of the Executive Committee, introduced the new members and promised to do his best for the progress of crystallography in the coming triennium. He then declared the Twentieth General Assembly and Congress closed. 